\title{
Analysis of Factors of Entrepreneurial Environment Formation of Small Business in the Republic of Crimea
}

\author{
Maidanevych Yu.P.* \\ Public and Municipal Administration Department \\ V.I. Vernadsky Crimean Federal University \\ Simferopol, Russia \\ e-mail: maidanevich@rambler.ru
}

\author{
Rotanov G.N. \\ Public and Municipal Administration Department \\ V.I. Vernadsky Crimean Federal University \\ Simferopol, Russia \\ e-mail: j.n.rotanov@gmail.com
}

\begin{abstract}
Environmental factors that form the business environment of the region and determine the development of small business in the Republic of Crimea are systematized and characterized. The factors inhibiting the development of small business in the region are identified. The strengths and weaknesses of the production potential of small businesses and the directions of leveling the influence of factors inhibiting the development of small business in the region are determined.
\end{abstract}

Keywords - entrepreneurship, small business, factors, operating conditions, internal environment, external environment, small business potential.

\section{INTRODUCTION}

Small business plays a leading role in the economy of the state, since it is the foundation for a market economy. This sector creates the necessary atmosphere of competition. It is able to respond quickly to any changes in market conditions, to create more jobs, to pay off relatively quickly. It is the main source of the middle class, because the middle class is the key to the stability of society and its successful development.

That is why in the current conditions of the economy development of Crimean Republic, the development of business, in particular small one, should become one of the most important factors of socio-economic growth, a real engine of the region's economy. The development of a small business directly depends on many factors that influence its development and functioning efficiency. Understanding the influence of each factor separately and in their totality on the development of small business will allow entrepreneurs to carry out their activities with the lowest risks, and permit the state to implement an effective policy to support its development.

The purpose of the research is to investigate the factors that form the entrepreneurial environment of small business in the Republic of Crimea and develop proposals to address the influence of factors that impede the development of small business in region.

\section{METHODS AND MATERIALS}

The study questions of small business development in the current market and political conditions are given sufficient attention by researchers and practitioners. Among them it is necessary to highlight K.A. Bedrik, Yu.P. Maidanevich [1], V.B. Bokarev [2], I.T. Ziyatdinov [4], I.A. Kiseleva, N.E. Simonovich, G.N. Yegorova, Yu.A. Shapovalov [5], A.D. Petrova, N.M. Blazhenkova, Ye.R. Kalimullina [6]. The researchers pay considerable attention to the study of factors affecting the development of small business, among them we distinguish the works of I.D. Borisov [3], Yu.M. Sokolinskaya, Ye.A. Kolesnichenko, K.V. Chekudaev [9] and D.R. Khairullina [10]. However, to ensure the development of small business in each separate region, it is necessary to understand the factors affecting the business and the degree of their influence the formation of the business environment in the changing conditions of the external and internal environment of region.

The methodological basis of the study became the fundamental provisions in the scientific works of foreign and domestic authors. In the course of the study the author used the following general scientific and economic methods: dialectical - to understand the laws of small business development; cognitive - to research factors influencing the development of entrepreneurship; abstract-logical - for theoretical generalization and formulation of conclusions; systematic, integrated and situational analysis - to assess the influence of factors on the development of small business.

\section{RESULTS OF THE STUDY}

Small business performs important socio-economic functions, such as balancing supply and demand in the goods and services market; creation of additional jobs; stimulation of the economic initiative of market participants; rational use of resource potentials; the solution of many social and economic problems. However, its presence in all the types of economic activity indicates the presence in that area of business people with long-term projects.

Small business is actually being revived in the Republic of Crimea under the prevailing political and economic conditions and has a number of specific features that objectively influenced the formation and development of the enterprise sector.

In the conditions of modern transformations in the region's economy, the development of small business is influenced by 
various factors inherited from the specific past, from the lack of a consistent and balanced economic policy of state authorities, from not always justified actions of local authorities. According to the degree of impact we can identify the factors that contribute to the establishment and development of small business and the factors hindering its development.

The analysis of factors influencing the activity of small businesses need to be performed simultaneously with the analysis of the business environment that is multiple of the inside and outside (Fig. 1). The external environment, as a rule, is independent of the business structures and is formed under the influence of external factors. The internal environment is formed directly by the entrepreneurs themselves [7].

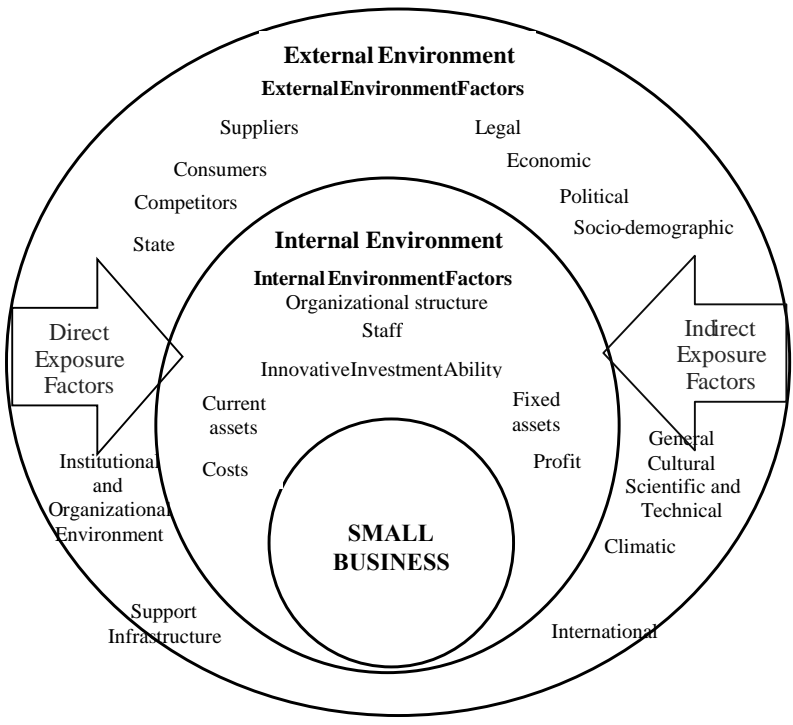

Fig. 1. Factors determining the development of small business in the Republic of Crimea. Compiled by the author.

The internal environment is a kind of potential that makes it possible to exist and function for a certain period of time. Among the internal factors, it should be noted: organizational structure, staff, fixed and current assets, innovative and investment abilities, costs and profits.

1. Organizational structure - an ordered set of interrelated elements that are interconnected in a stable relationship, which ensure their functioning and development as a whole.

2. Staff - a collection of all the human resources that the organization has. They are employees of the organization, as well as partners who are involved in the implementation of certain projects, experts, who may be involved in research, strategy development, implementation of specific measures and the like.

3. Fixed assets - a set of assets produced by social labor material assets that have been operating for a long period. The fixed assets in the market economy include land, buildings, structures, transfer devices, machines, equipment, vehicles, tools, production and farm implements, working and productive livestock and others.
4. Current assets - a collection of assets of the enterprise, advance in the creation of revolving funds and the treatment and ensure their continuous circulation of funds.

5. It is proposed to consider the innovative and investment ability of an enterprise as a potential or realized ability to aggregate and use a combination of organizational, technical, financial, material, labor, information, legal, communication opportunities that allow performing functions and solving tasks aimed at any socio-political level to achieve the set development goals for a certain period of time in the implementation of innovation and investment activity of the enterprise.

6. Consumption - is to reduce the volume of material assets, money, etc., that occur in the process of conscious human activity; reduction of certain resources in physical processes.

7. Profit - one of the main sources of financial resources and the formation of venture funds of the enterprise. About $95 \%$ of profit is used for operating activities [10]

The external environment is a source of resources to support internal capacity. After all, the company is in a state of constant exchange with the external environment. Since these resources are limited and competitors also apply for them, a threat may arise in which the company does not receive the resources it needs, which will lead to negative consequences. Among external factors, it is important to consider: legislative support of the state, tax policy of the state, credit and financial policy of the state, innovation and investment policy of the state, information security of the enterprise, cultural support of the enterprise by the state.

1. Legislative support of the state consists in the development of small business in Russia and the Republic of Crimea. It is implemented by the relevant national, regional and local authorities with the aim of harmonizing the interests of the state and small and medium enterprises. In recent years, significant attention has been paid at the government level to building a system of state support for small business. This is evidenced by recent legislative and regulatory acts. In recent years, much has been done to develop small business in Russia and in the Republic of Crimea. Relations connected with the development of small business in Russia, based on the Constitution and regulated by the Commercial, Civil and Tax Codes of the Russian Federation, laws and regulations, as well as Russia's international agreements. The main law in the field of entrepreneurship is Federal Law No. 209-FL "On the Development of Small and Medium-Sized Enterprises in the Russian Federation" accepted on July 24, 2007. At the regional level, the State Council of the Republic of Crimea adopted the Law of the Republic of Crimea "On the Development of Small and Medium-Sized Enterprises in the Republic of Crimea" on July 9, 2014.

2. The tax policy of the state is reflected in the Tax Code of the Russian Federation. The tax code of the Russian Federation establishes the procedure and features of taxation of business entities. 
In order to provide state support for small business in the Russian Federation, the following taxation systems for small businesses are implemented:

- generally established for all entities engaged in entrepreneurial activity, i.e., the general taxation regime;

- $\quad$ simplified system installed by chap. 26.2 of the Tax Code of the Russian Federation;

- taxation system in the form of a single tax on imputed income for certain types of activities established by chap. 26.3 of the Tax Code of the Russian Federation.

The last two systems are related to special tax regimes.

The budget code of the Russian Federation regulates the provision of subsidies, subventions, etc.

3. The credit and financial policy of the state is to ensure the legislative procedure for providing enterprises with borrowed funds. The microcredit program for small businesses with the participation of banking and non-banking structures remains legally unprocessed. It should be noted that Ukrainian banks are picky about representatives of small and mediumsized businesses and, despite numerous advertisements on favorable conditions for small and medium-sized businesses, are reluctant to provide loans, especially long-term ones. In the process of their activities, small and medium enterprises have to deal with many factors that can have both positive and negative impact on their functioning in various industries. The role of the state is to create such conditions in which these factors should have a positive impact, otherwise, to minimize their negative impact.

4. Innovation and investment policy of the state is the activity of the state aimed at creating favorable regulatory and economic conditions for investments in general and investments in innovations, stimulating the process of creating investment conditions for innovative development, as well as creating an innovation and investment market.

Innovation and investment policy of the state should be aimed at ensuring the growth of investment in the implementation of innovative technologies [2].

The state, using certain mechanisms, contributes to the creation of conditions for the formation and stimulation of the investment and innovation development, primarily through the creation of a positive investment climate due to the improvement of the overall international country image.

The influence of the state should be carried out through the application of a system of organizational and informational measures and financial support, namely the development of a regulatory framework for innovation and investment activity; developing a strategic development program; determination of the optimal level of state ownership.

The important mechanism for ensuring innovative directed industrial policy is to determine the priorities of the country's strategic development; they should take into account the general increase in the level of science, technology, and production. Prioritization is only the beginning, as even more important is the development of programs that will ensure their implementation and provide for appropriate funding.

5. Information security of the enterprise - is characterized by confidentiality, integrity, accessibility and can be considered as a combination of the following elements: safe conditions for the functioning of information technologies, the construction of an effective infrastructure of the information space, a holistic information market, the creation of optimal conditions for the passage of information processes. Ensuring the invariability of the existing order of information systems functioning should occur at three levels: administrative - with the help of the formation of specific rules and recommendatory standards for staff, object - the use of certified, legal means of software and hardware [3].

One of the most effective methods for optimizing the level of information security is a specific program of state policy in this area, which should be formed in accordance with the norms of current legislation.

D.R. Khairullina calls one of the methods of ensuring the information security of the enterprise the standardization of the information structure of the information system, the elements of which are the forms of existence and presentation of information as a whole, and the connections are information conversion operations in the system. The standardization of this type is the introduction of uniform rules for input, storage, analysis, processing of information [10]

6. Cultural support of an enterprise by the state is regulated by the Law of the Russian Federation "Fundamentals of the Legislation of the Russian Federation on Culture", according to which institutions, enterprises, organizations and cultural institutions are provided with priority video, television, radio, cinema equipment, technical means, musical instruments, furniture, stage equipment, paper and other materials necessary for the implementation of professional, cultural and educational activities.

It is important to note that the influence of internal and external factors on the activities of small businesses has certain dependence. Particular interest is paid to the proportion of the risk assessment activities, obtained under the influence of factors of external origin, that is, how much of the risk of the company is not able to control, since external factors can only be taken into account, and manage them is not possible. The company can manage internal factors.

Among the factors hindering the development of small business in the Republic of Crimea are the following:

- actual isolation of the peninsula (sanctions imposed the work of international seaports was paralyzed, Simferopol airport turned from international to local, all export and import operations were stopped, the banking sector was damaged, sales of international brands were curtailed, etc.);

- organizational and legal difficulties of starting a business, especially at the stage of transition from registration to the beginning of activity, associated with a lack of experience in the legal field of the Russian Federation; 
- inaccessibility of credit resources for opening and running a business or its restoration, lack of practice of relations with international financial organizations to attract investments and grants;

- mainly the declarative nature of state support, the ambiguity and inconsistency of the current regulatory framework;

- territorial imbalances, that is, the concentration of small enterprises around industrial centers and their almost absence in remote areas and villages;

- unfavorable tax policy, exorbitant burden of taxation (especially in matters of payroll, which leads to significant shadowing in small businesses), in addition, lack of knowledge and experience in tax accounting in accordance with the legislation of the Russian Federation;

- cumbersome system of accounting and reporting;

- weakness of the small business infrastructure, lack of professional knowledge and experience.

In order to mitigate the impact of the above factors, it is necessary to understand the potential of the small businesses in the region. Let us carry out SWOT-analysis of individual elements to productive capacity of small enterprises of the Republic of Crimea, which will allow allocating reserves in this sector of the economy, as well as to identify the main ways of development of small businesses (Tab. 1).

TABLE I. STRENGTHS AND WEAKNESSES OF THE PRODUCTION POTENTIAL OF SMALL ENTERPRISES OF THE REPUBLIC OF CRIMEA

\begin{tabular}{|c|c|c|}
\hline & Strengths & Weaknesses \\
\hline & $\begin{array}{l}\text { 1. There is a system of technical and } \\
\text { technological maintenance of equipment. } \\
\text { 2. Availability of qualified personnel. } \\
\text { 3. Professional development of existing and } \\
\text { new human resources. } \\
\text { 4. Updating the technological park of } \\
\text { equipment. } \\
\text { 5. Development of existing equipment } \\
\text { maintenance schedules. }\end{array}$ & $\begin{array}{l}\text { 1. Lack of tactical work planning in the field of } \\
\text { technical and technological equipment maintenance. } \\
\text { 2. Lack of development strategies for technical and } \\
\text { technological services. } \\
\text { 3. Lack of clear internal coordination of operations. } \\
\text { 4. Lack of a systematic and planned system for } \\
\text { documenting the results of work. } \\
\text { 5. Lack of a well-functioning logistics system. } \\
\text { 6. The high cost of resources and materials. } \\
\text { 7. The presence of unskilled personnel in some } \\
\text { specialties. } \\
\text { 8. Frequent damage to equipment and individual } \\
\text { components. } \\
\text { 9. Lack of regular supply of enterprises with new } \\
\text { equipment, spare parts. } \\
\text { 10. The high cost of production, work and services. }\end{array}$ \\
\hline $\begin{array}{l}\text { Opportunities } \\
\text { 1. Improvement of the efficiency of small and medium- } \\
\text { sized enterprises. } \\
\text { 2. Improvement of the quality of the workforce of the } \\
\text { enterprise. } \\
\text { 3. Improvement of the quality of training of employees } \\
\text { in engineering specialties. } \\
\text { 4. Prevention of problems. } \\
\text { 5. Reduction of the cost of work and services. } \\
\text { 6. Benchmark of quality customer service. } \\
\text { 7. The search for reserves to reduce the cost of } \\
\text { production, work, services. } \\
\text { 8. Clear supply and work with suppliers. } \\
\text { 9. Implementation and development of time } \\
\text { management. }\end{array}$ & $\begin{array}{l}\text { 1. Organization of the operation of the } \\
\text { equipment maintenance system in accordance } \\
\text { with the principles of management. } \\
\text { 2. Reduction of resources spent on equipment } \\
\text { maintenance. } \\
\text { 3. Perhaps the introduction of advanced } \\
\text { management methods. } \\
\text { 4. Improvement of the quality of service, work. } \\
\text { 5. Improvement of labor productivity and } \\
\text { equipment. } \\
\text { 6. Development of the competitiveness of } \\
\text { small businesses. } \\
\text { 7. Elimination of losses associated with equipment. } \\
\text { 8. Expansion of the assortment of products, } \\
\text { work performed, services rendered. } \\
\text { 9. Attraction of new qualified professionals in } \\
\text { the industry. } \\
\text { 10. Targeting new customers. }\end{array}$ & $\begin{array}{l}\text { 1. The lack of proper and quality planning of } \\
\text { enterprises does not contribute to improving the } \\
\text { efficiency of small businesses. } \\
\text { 2. The lack of a well-functioning procurement } \\
\text { system, as well as an analysis of the operation of the } \\
\text { equipment, does not contribute to a clear work with } \\
\text { suppliers. } \\
\text { 3. Constantly increasing costs for the production of } \\
\text { works, the provision of services do not contribute to } \\
\text { increasing the competitiveness of the enterprise. } \\
\text { 4. The lack of a systematic and orderly } \\
\text { documentation of the results of the qualitative } \\
\text { service prevents consumers of goods, works and } \\
\text { services in the sphere of small business. }\end{array}$ \\
\hline $\begin{array}{l}\text { Threats } \\
\text { 1. A decrease in the volume of output, production of } \\
\text { works, and the provision of services. } \\
\text { 2. Imperfect management structure of small businesses. } \\
\text { 3. The increase in the requirements of potential } \\
\text { consumers for manufactured products, works, services. } \\
\text { 4. Poor quality of raw materials used. } \\
\text { 5. The dependence of the quality of the work result on } \\
\text { the personal qualities of the performers. } \\
\text { 6. Great dependence on suppliers of raw materials. } \\
\text { 7. High competitiveness in the market of works and } \\
\text { services. } \\
\text { 8. Higher prices for equipment, spare parts and } \\
\text { consumables. } \\
\text { 9. Low motivation of staff in the results of labor. }\end{array}$ & $\begin{array}{l}\text { 1. Reducing the risk of productivity is possible } \\
\text { due to the introduction of new equipment in } \\
\text { production. } \\
\text { 2. The ability to optimize management costs by } \\
\text { attracting qualified specialists to the industry. } \\
\text { 3. Prevention of equipment breakdowns due to } \\
\text { the maintenance of equipment in accordance } \\
\text { with the grapheme. } \\
\text { 4. Reduction of the risk of customer } \\
\text { dissatisfaction with the quality of products, } \\
\text { work and services due to operational } \\
\text { maintenance of equipment. } \\
\text { 5. Reduction of the risk of losing } \\
\text { competitiveness by updating the assortment } \\
\text { and developing the market. }\end{array}$ & $\begin{array}{l}\text { 1. The decline in the quality of products, works, } \\
\text { services as a result of the lack of regular tactical and } \\
\text { strategic planning in the field of small business. } \\
\text { 2. High repair costs and simple equipment are } \\
\text { associated with the presence of unskilled personnel } \\
\text { in the small business. } 3 \text {. Ineffective motivation } \\
\text { system for stimulating employees of small } \\
\text { businesses to reduce the stability of enterprises in the } \\
\text { market. } \\
4 \text {. Reduction of the amount of products, works and } \\
\text { services by small businesses due to the fact that they } \\
\text { are dependent on suppliers that set high prices for } \\
\text { resources and materials. }\end{array}$ \\
\hline
\end{tabular}

9. Low motivation of staff in the results of labor. Source: compiled by the author 
Thus, the SWOT analysis of individual elements of the production potential of small businesses in the Republic of Crimea revealed the main problems typical for enterprises in this sector of the economy:

1. The decline in the quality of products, works, services as a result of the lack of regular tactical and strategic planning in the field of small business.

2. High repair costs and equipment downtime are associated with the presence of unskilled personnel in the small business.

3. Ineffective system of motivation and incentives for employees of small businesses contribute to reducing the stability of enterprises in the market.

In addition, the results of the SWOT analysis allow identifying new promising opportunities for the development of small business in the Republic of Crimea:

1. Reducing the risk of productivity is possible due to the introduction of new equipment in production.

2. The ability to optimize management decisions by attracting qualified specialists to the industry.

3. Prevention of equipment breakdowns due to implementation in accordance with the equipment maintenance schedule.

4. Reducing the risk of customer dissatisfaction with the quality of products, work and services due to operational maintenance of equipment.

5. Reducing the risk of losing competitiveness by updating the assortment and developing the market.

The Republic of Crimea has sufficient potential for the development of small business. Despite the weaknesses that limit the quantitative and qualitative growth of production and enterprises in this sector of the economy, the production potential of the Republic of Crimea has strengths, thanks to which it is possible to develop small businesses in the region.

\section{CONCLUSION}

The study revealed negative influences on the development and operation of a small business in the Republic of Crimea, including the following:

- imperfect and contradictory regulatory framework;

- $\quad$ lack of clearly formulated in the system of legal acts of state policy in the field of small business support;

- an increase in administrative barriers (registration, licensing, certification, control systems and licensing practices, regulation of rental relations);

- excessive number and arbitrariness of regulatory bodies employees;

- vague "rules of the game" of small business, the uncertainty of entrepreneurs in the stability of the business environment;

- $\quad$ competition from large businesses;
- $\quad$ low demand;

- inflation

- the provision of benefits or benefits to individual business entities by state bodies;

- lack of real and effective mechanisms for financial and credit support;

- excessive interference of public authorities in the activities of business entities and corruption;

- lack of support for cooperation between large and small business entities;

- excessive tax pressure and a burdensome reporting system.

All these factors are part of the business environment. That is, the entrepreneurial environment for the functioning of small business in the Republic of Crimea can be assessed as unsatisfactory and requiring further improvement.

The solution of the existing problems of small business development in the Republic of Crimea, the creation of an appropriate business environment require the improvement of state policy in the field of promoting small business, primarily due to: improvement of legal, economic and organizational conditions for the sustainable development of small business as an important factor in the development and structural adjustment of the economy; purposeful formation of a system of state and public support for small businesses through appropriate software, expanding the sector of the provision of infrastructure services (information and consulting, marketing, etc.); stimulating the development of small enterprises in the production, innovation and social spheres, creating new jobs, supporting business and investment, developing competition in the market of goods and services by improving tax, labor laws, strategies and innovative development programs; initiation of financial credit and investment mechanisms, as well as new sources of financing business activities, first of all, due to the own capabilities of small enterprises, effectively developing formations of the developed infrastructure of small business at the national, regional and local levels; creation of a layer of business owners by creating incentives for selfdevelopment of small business.

All of these areas forming respective small business development environment are functioning only partially, and are contradictory and discrete, it will require a detailed analysis and improvement, because that state is able to not only maintain, but should initiate the development and implementation of appropriate conditions for the business environment.

\section{References}

[1] K.A. Bedrik, Yu.P. Maydanevich, "Development of small business in the Republic of Crimea: problems and prospects", pp. 24-27, 2018 [Digests Int. Conf. "Management in the conditions of global transformations: economics, politics, law", 2018].

[2] V.B. Bokareva, "Social management of the external and internal environment of a small business in Russia", Philos. of Econ. and Econ. Sci., pp. 126-132, 2012 
[3] D.I. Borisov, "The influence of environmental factors on the development of small business in Russia", ECONOMINFO, vol. 21, pp. 25-27, 2014.

[4] I.T. Ziyatdinov, "Methods of state support for small and medium-sized enterprises", Student forum: Electr. Sci. J., vol. 3, no. 3, 2017. Retrieved from: https://nauchforum.ru/journal/stud/3/19299/

[5] I.A. Kiseleva, N.E. Simonovich, G.N. Yegorova, Yu.A. Shapovalov, "Methods for assessing and managing entrepreneurial risks", Bull. of Voronezh State Univer. of Engineer. Technol., vol. 79, no. 2, pp. $314-319$, 2017.

[6] A.D. Petrova, N.M. Blazhenkova, E.R. Kalimullina, "The role of entrepreneurship in economic development of the region", Bull. of Voronezh State Univer. of Engineer. Technol., vol. 79, no. 1, 2017.
[7] Yu.S. Pinkovetskaya, "Small and medium enterprises in the regions: production functions", Product. Organizer, vol. 1, pp. 18-24, 2014.

[8] Yu.M. Sokolinskaya, "Model of interaction between the state and small business", Bull. of Voronezh State Univer. of Engineer. Technol., vol. 81, no. 1, pp. 449-456, 2019.

[9] Yu.M. Sokolinskaya, Ye.A. Kolesnichenko, K.V. Chekudaev, "Importance of small business in the economy and factors constraining its development", Bull. of Voronezh State Univer. of Engineer. Technol., vol. 81, no. 3, pp. 360-363, 2019.

[10] D.R. Khairullina, "Factors determining the development of small businesses", Manag. of Econ. Syst.: Electr. Sci. J., vol. 3, no. 97, 2017. Retrieved from: https://cyberleninka.ru/article/n/faktoryopredelyayuschie-razvitie-malogo-biznesa/ 